J. Product. \& Dev., 24(4): 885 - 903(2019)

\title{
HERBICIDAL EFFECTS ON BIOCHEMICAL COMPONENTS AND YIELD IN RICE PLANTS (Oryza sativa L.)
}

\author{
Ahmed E.A.M. El-Sobki \\ Plant Prot., Depart., Fac. Agric., Zagazig Univ., Egypt \\ e.mail:elsobki2006@yahoo.com
}

\section{ABSTRACT}

This investigation was carried out in a demonstrated field at AlIbrahimia district, El-Sharkia Governorate, Egypt, during 2019 season to study the effect of four postemergence herbicides namely, halosulfuron-methyl, fenoxaprop-p-ethyl, bispyribac-sodium and bensulfuron-methyl compared with control treatment under four rice cultivars (Egyptian hybrid rice 1" EHR1", Sakha 104, Giza 179 and Giza 178) on photosynthetic pigments and total carbohydrate, protein content, essential and non-essential amino acids.

The obtained results revealed that, no health problems were noticed for all rice varieties on the different experimental area. The lowest values of photosynthetic pigments and total carbohydrate were recorded for halosulfuron-methyl herbicide compared with other herbicides or control treatment. Addition of herbicides led to significant decrease in non-essential amino acids and protein content but, Aspartic amino acid was increased with application of bensulfuron-methyl herbicide. But, rice yield components were significantly incresaesed due to foliar application of herbicide. On other hand, EHR1 gave the highest values for physiological and biochemical parameters as compared with the other varieties. On other side, Sakha $104 \mathrm{cv}$. appeared to produce the highest number of panicle per $m^{2}$,seed index and grain yield/fad. The interaction between factors under study had significant effects on physiological and biochemical parameters and yield components of rice were the results suggested that there a complementary effect between weed control treatments and rice cultivars by sowing Sakha $104 \mathrm{cv}$. and EHRI with application of the tested herbicides.

The physiological and biochemical models of dual-herbicidetolerant rice cultivars adds further informations to the knowledge of the crop herbicide tolerance degree for sustainable weed management in recent agricultural system. 
Conclusively, The results of the study showed a decrease in the activity of physiological and biochemical content as response to the tested herbicide treatment at the recommended rates, and this was reflected in the values of essential and non-essential amino acids in the tested rice varieties. The rice crop components were also highly significant due to the application of herbicides.

Keywords: Biotoxic, herbicides, cultivars, rice, yield components, protein, carbohydrate, photosynthetic.

\section{INTRODUCTION}

Rice (Oryza sativa L.) is one of the most important strategic cereals not only in Egypt but in almost worldwide. In Egypt, rice area is about half million hectares with average yield of 10 tons/ ha. This significantly high productivity is mainly due to the improvement of short duration varieties with a higher yield potential, as well as, resistance to a biotic and biotic stresses (Khattab, 2019). Weeds are one type of biotic stress which led to cause severe reduction in rice productivity. Traditional methods of weed control with manual weeding increases the cost of cultivation (Singh et al., 2016).

In rice agricultural systems, the aim of herbicide is to kill or decrease weed infestation allowing the rice to grow. Herbicides are the major methods of weed control in rice fields in Egypt but there are certain negative impacts on some environmental systems. The other important role of herbicides, can provide effective and economic control in rice field, it is saves labour cost up to 40\% (Saha et al., 2018). Chlorophyll is the main instrument responsible for photosynthesis. Carotenoids are natural pigments with substantial applications in nutraceutical and pharmaceutical, food industries (Jinendiran et al., 2019), it is provide several biological functions in micro-organisms and plants such as in photoprotection (Britton et al., 2004). Herbicides exhibited some phytotoxic effects on crop plants (Sundaru, 1983, Nandihalli and Bhowmik, 1992, Singh et al., 1996, Kushwaha and Bhowmik, 1999, Thapa, 2012, Singh et al., 2016, Tagour and Mosaad, 2017, Saha et al., 2018). A number herbicides such as halosulfuron-methyl, fenoxaprop-p-ethyl, bispyribac-sodium and bensulfuronmethyl etc. have been recommended as post-application against rice weeds (Saha et al., 2018). These herbicides are useful in growth rice field to control the early weeds. All these herbicides have differential biotoxic effects on the target crops and their associated weeds flora.

The effects of herbicides were physiological changes and disturbances in cell division (Singh, 2007, Kumar and Singh, 2010), carbohydrate content and caused changes in gene mutation (Kumar, 2012), inhibits the synthesis of 
protein (Egli et. al., 1985 and Benmoussa et al., 2000). Also, Ahmed et al., (2019) determined the effects of glyphosate herbicide on the total chlorophyll, percent of death and injury level in Alfalfa plants. Plants can synthesize everything they need to survive, including amino acids (Shaner, 1989). Sands and Pilgeram (2009) foud that glyphosate and imidazolinone herbicides can be inhibited by the exogenous addition of certain amino acids. Also, FernándezAparicio et al. ( 2017) who stated that, certain amino acids induce inhibitory effects as herbicides in plant growth due to feedback inhibition of metabolic pathways and amino acids. For efficacious action on weeds flora, the herbicides are applied on the foliage of herbicides-tolerant crop cultivars. Herbicides application or hand weeding had the highest rice yield and yield attributes compared with control treatment (Pasha et al., 2012, Shukla et al., 2015).

With respect to varietal differences, several investigators reported significant differences between rice cultivars in photosynthetic pigments and total carbohydrate, protein content and amino acids (Kamara et al., 2010, Thapa, 2012, Zayed et al., 2014, Zhou et al., 2018, and Khattab, 2019). Also, several authors reported significant increase of grain yield and yield attributes due to rice varietal differences (Abou-Khalifa, 2012, Abou Khalifa et al., 2014, Gomaa, 2018 and Khattab, 2019).

Therefore, this study towards to understand the biotoxic effects of the foliar selective post-emergance herbicides on tolerance of potential rice cultivars, which may be the important step for designing the integrated weed management program.

\section{MATERIALS AND METHODS}

An open field experiment was implemented in a demonstrated field at Al-Ibrahimia district, El-Sharkia Governorate, Egypt, during 2019 season. The analyses of the soil, showed that the soil was clay in texture, organic matter (2.0\%), total $\mathrm{N}(0.15 \%)$, available $\mathrm{P}(17 \mathrm{ppm})$, available K (140 ppm), and $\mathrm{pH}$ (7.9 "moderately alkaline").

The present study aimed to find out the effect of four selective postemergance herbicides (halosulfuron-methyl, fenoxaprop-p-ethyl, bispyribacsodium and bensulfuron-methyl) compared with control treatment under four rice cultivars (EHR1, Sakha 104, Giza 179 and Giza 178) on photosynthetic pigments, total carbohydrate, protein content and essential and non-essential amino acids. The tested herbicides were halosulfuron-methyl (Inpul 75\% WG $)^{\mathrm{R}}$, at rate $20 \mathrm{~g} /$ fad., supplied by Shoura Chemicals, Egypt. fenoxapropp-ethyl (Whip- super $7.5 \% \mathrm{EW})^{\mathrm{R}}$, at rate $350 \mathrm{~cm}^{3} /$ fad., supplied by Bayer Crop Science, Egypt, bispyribac-sodium (Vogal $30 \% \mathrm{WP})^{\mathrm{R}}$, at rate $100 \mathrm{~g}$ / 
fad., supplied by Shoura Chemicals, Egypt and bensulfuron-methyl (Reto 60 $\% \mathrm{WG})^{\mathrm{R}}$, at rate $50 \mathrm{~g} /$ fad., supplied by Shoura Chemicals, Egypt.

Five treatments were sprayed against the weeds associated with cultivars rice plants using a knapsack sprayer (5 liters/plot) where, the selective herbicides were applied once at based on the recommendations of the Egyptian Ministry of Agriculture for each herbicide after sowing and in control treatment. Phosphorus at a level of $15.5 \mathrm{~kg} \mathrm{P}_{2} \mathrm{O}_{5} / \mathrm{fad}$, as ordinary superphosphate $\left(15.5 \% \mathrm{P}_{2} \mathrm{O}_{5}\right)$ was incorporated at the time of seeding. Rice grains, sowing at the rate of $60 \mathrm{~kg} / \mathrm{fad}$ and were soaked in water for $24 \mathrm{~h}$, then drained and incubated for $12 \mathrm{~h}$ to motivate and enhance germination percentage. In wet leveled plots, Per-germination seeds were manually planting in hills at $20 \mathrm{~cm}$ between rows $\times 20 \mathrm{~cm}$ between hills on $20^{\text {th }}$ May. Nitrogen fertilizer was applied as urea $(46.5 \% \mathrm{~N})$ in three splits after 20, 40 and 55 day after sowing (DAS).

The preceding crop was wheat (Triticum aestivum). A split plot design of four replications was used, where the herbicides treatments were allocated in the main plots whereas cultivars were allocated in the sub plots $\left(9 \mathrm{~m}^{2}\right)$. Soil samples were collected from the experimental sites at the depth of $0-30 \mathrm{~cm}$ before planting to determine soil physical and chemical properties at the Central Laboratory of Faculty of Agriculture, Zagazig University, Zagazig, Egypt.

\section{Measuring phytotoxicity of the tested herbicides on the rice cultivars.}

After $72 \mathrm{~h}$ of treatment fresh leaves were collected to determine chlorophyll a (Chl. a), chlorophyll b (Chl. b) and carotenoids according to Fideel's method (Fideel, 1962). The optical density was measured using spectrophotometer Jenway-6405-UV/VIS at 662, 644 and $440 \mathrm{~nm}$ to determine the photosynthetic pigments (Chl a, Chl. $\mathrm{b}$ and carotenoids) as $\mathrm{mg} / \mathrm{g}$ fresh weight $(\mathrm{FW})$, respectively. The pigments concentration was calculated using the formula adapted by Wettestein (1957).

Chl. a $(\mathrm{mg} / \mathrm{L})=(9.784 \times \mathrm{E} 662)-(0.99 \times \mathrm{E} 644)$.

Chl. b $(\mathrm{mg} / \mathrm{L})=(21.426 \times \mathrm{E} 644)-(4.64 \times \mathrm{E} 662)$.

Carotenoides $(\mathrm{mg} / \mathrm{L})=(4.695 \times E 440.5)-[0.268 \times(\mathrm{Chl} . \mathrm{a}+\mathrm{Chl} . \mathrm{b})]$.

Where, $\mathrm{E}$ is the reading of the optical density at given wave length.

\section{Estimation of total carbohydrate, protein content and amino acids}

After $72 \mathrm{~h}$ from spraying, samples of the tested rice cultivars leaves were randomly taken from each plot to determine each total carbohydrate and crude protein content (A.O.A.C., 2000). Amino acids were extracted from oven dry leaves using ethyl alcohol $(80 \%, \mathrm{v} / \mathrm{v})$. The quantitative and qualitative amino acids determination was carried out according to Christias et al. (1975). 
The reduction percentage of phytotoxicity of herbicides was calculated according to Thapa(2012) by the formula.

Reduction percentage $=($ Control - Treatment $) /$ Control $x 100$

At harvest (end of August), the number of panicle per $\mathrm{m}^{2}$ and the following yield attributes were recorded on ten panicles, i.e., filled grains no./ panicle and 1000 grain weight. Also, the following final yield traits were recorded from a central area of $1 \mathrm{~m}^{2}$ per plot: grain yield at grain moisture content of $14 \%$ and harvest index (\%).

\section{Statistical analysis}

The obtained data were statistically analyzed as mentioned by Gomez and Gomez (1991) using the computer MSTAT statistical analysis package (MSTAT-C, 1991).

Least significant differences (LSD) method was used to test the differences between treatment means at 5\% level of probability as described by Steel et al. (1997).

\section{RESULTS AND DISCUSSION}

\section{Photosynthetic pigments and total carbohydrate content}

The effects of herbicides and cultivars and their interaction on physiological components, photosynthetic pigments; chlorophyll a, chlorophyll $b$ and total chlorophyll $(a+b)$, carotenoids, as well as, total carbohydrate in rice plants are shown in Tables ( 1 and 1 continued).

Insignificant $(\mathrm{P}<0.05)$ highly differences were observed in photosynthetic pigments and total carbohydrate were observed due to application of herbicides treatments under the four cultivars of rice. It is clear from the results that, spraying herbicides (halosulfuron-methyl, fenoxaprop-pethyl, bispyribac-sodium and bensulfuron-methyl decreased significantly chl. a (18.10, 15.36, 1.86 and 4.99\%), chl. b (41.52, 37.59, 27.64 and 30.52\%) and total chl $(\mathrm{a}+\mathrm{b})(32.12,28.66,17.24$ and $20.22 \%)$, carotniods were recorded $(14.77,11.90,2.20$ and $13.52 \%$ ) as well as total carbohydrate $(10.51,9.77,8.17$ and $6.57 \%)$ as reduction percentage in rice leaves compared with control treatment, respectively. Moreover, the lowest values for photosynthetic pigments and total carbohydrate were recorded by foliar application of halosulfuron-methyl herbicide than those obtained herbicides or control treatment. On other hand, the results revealed that, varietal differences 
were significantly $(\mathrm{P}<0.05)$ affected on photosynthetic pigments and total carbohydrate where, EHR1 gave the highest values for either photosynthetic pigments or total carbohydrate content as compared with those recorded by Sakha 104, Giza 179 and Giza 178 cvs., respectively.

According to the interaction effect between herbicides treatments and cultivars, it is interesting to mention that, under the check treatment for herbicides with sowing of EHR1 significantly increased photosynthetic pigments and total carbohydrate content as compare with foliar application herbicides under the other cultivars. Contrary to this, Giza $178 \mathrm{cv}$. was the most varieties negatively affected by herbicides where, the lowest values for photosynthetic pigments and total carbohydrate achieved by foliar application of halosulfuron-methyl herbicide. These results are in harmony with Ahmad et al., (2007), Saleem et al., (2011) and Hanci and Cebeci (2014) they suggested that the chlorophyll and carotenoids contents usually decreases and reduction in the plants exposed to environmental stresse. Also, Kumar (2012) who showed that, application of herbicides (2, 4-D and IPU) were able to reduce total soluble carbohydrate in plant. Butachlor slightly affected rice leaves chlorophyll and amino acids and although exhibited phytotoxic effects on plants, but, the symptoms disappeared 14 DAS (Thapa, 2012).

Rate of photosynthesis affected adversely due to inactivation of chlorophyll (Amirjani and Mahdiyeh, 2013). On other hand, Giza178 cv. significantly had higher plant pigments and photosynthesis comparing to other varieties; Giza177 and Sakha 104 ( Zayed et al., 2014). Also, Giza 178 cv. achieved the highest photosynthetic pigments content (Chl. a \& b and Carotenoids) followed by Giza $182 \mathrm{cv}$. which recorded the lowest value (Khattab, 2019).

\section{Essential amino acid and total essential amino acid}

Application of herbicides caused significant decrease in both the essential amino acids namly, Lysine, Methionine, Cysteine, Threonine, Isoleucine, Leucine, Tyrosine, Valine and total essential amino acids in rice plant ( 2 and 2 continued). The lowest values for essential amino acids and total essential amino acids achieved by foliar application of halosulfuronmethyl herbicide compared with other herbicides or control treatment, may be due to the effect of halosulfuron-methyl inhabition of acetolactate synthase(ALS) responsible for biosynthesis of the branched chainamino acid such as valin, leucin and isoleucine (Saari et al., 1990). At contrary, Phenylaine amino acid was increase by application of halosulfuron-methyl 
herbicide as a compared with the other treatments. Otherwise, the essential amino acids and total of its where appeared to be increased by control 
treatment. These results are quite interesting as they indicate that, addition of herbicides were effective to reduce the photosynthetic pigments (chl. a \& b and carotenoids) (Tables 1 and 1continued) and were reflected on essential amino acids and total essential amino acids in rice plants.

Respecting varietal differences results, highly significant differences $(\mathrm{P}<0.05)$ were observe, mean through, EHR1 gave the highest values for essential amino acids and total essential amino acids in rice plant as compared with those recorded by the other cultivars viz. Sakha 104, Giza 179 and Giza 178, respectively. Concerning the influence of interaction between herbicides treatments and cultivars on essential amino acids, as well as, total essential amino acids, the results revealed highly significant differences. It is important to note that, the Giza $178 \mathrm{cv}$. was the most varieties severe affected by herbicides where, the lowest values for almost essential amino acids and total essential amino acids achieved by application of halosulfuron-methyl herbicide, which followed by Giza 179, Sakha 104, and EHR1, respectively.

However, the highest values for almost essential amino acids and total essential amino acids were achieved through by the control treatment and planting of EHR1. Similar significant effects were reported by Scheel and Casida (1985) who showed that, chlorsulfuron and sulfometuronmethyl decreased the amino acids synthesis (isoleucine, leucine and valine) by blocking the acetolactate synthase pathway. Also, Zarzecka and Gugala (2003) showed that, the herbicides can have certain effects on changes in plant physiological process. Souahi et al. (2016) stated that, herbicides effect on all aspects of primary and secondary metabolisms in the tested crops when given to control the weeds. (Fernández-Aparicio et al., 2017) found that when assayed the highest herbicides concentration showed sensitivity to alanine, cysteine, histidine, isoleucine, leucine, methionine and tyrosine and the inhibition percnt depend on plant species and the plant growth stage. Zayed et al. (2014) who found that, Giza178 cv. significantly had higher amino acids comparing to other varieties; Giza177 and Sakha 104.

\section{Non- essential amino acids and protein content}

With respect to the influence of herbicides on non- essential amino acids and protein content in rice plants, the results showed that insignificant highly differences were observed in non- essential amino acids viz. Aspartic, Serine, Proline, Glysine, Alanine, Histidine and Arginine, as well as, protein content were observed due to application of herbicides treatments under the four cultivars of rice (Tables 3 and 3 continued). Addition of herbicides led to 
significant decrease in non-essential amino acids and protein content, by contrast, Aspartic amino acid was increased with application of bensulfuron- 
methyl herbicide. Otherwise, most non-essential amino acids, as well as, protein content appears to increase with the control treatment. On other hand, the results revealed that, varietal differences were significantly affected on non- essential amino acids and protein content in rice. A same trend, EHR1 gave the highest values for either non-essential amino acids or protein content as compared with those recorded by Sakha 104, Giza 179 and Giza 178 cvs., respectively (Tables 3 and 3 continued). Similarly, Giza $178 \mathrm{cv}$. was the most varieties affected by herbicides as compare with other rice cultivars where, the lowest values for non-essential amino acids and protein content caused by foliar application of halosulfuron-methyl herbicide which followed by Giza 179, Sakha 104 cvs., and EHR1, respectively. However, the highest values for the same traits were achieved through by control plot and planting of EHR1.

Generally, our results indicated that, exposure to the herbicides causes significant variation in essential, non-essential amino acids, protein content. Also, post-emergance herbicides tolerant-varieties are not always available for many crop species. Early, Omokawa et. al. (1988) found that, The N-(2,6Diethylphenyl)-N- nutoxymethyl 2-chloro-acetamide inhibits the protein synthesis in the rice plant. The noticeable decrease in carbohydrates and protein content of different plants in relation to applied herbicides might be due to the disturbing influence of such toxicants on enzymes involved in metabolic pathway of above mentioned components and supported the various reports (Yin et al., 2008, Hasaneen et al., 2009, Rosenbom et al., 2010, Hala et al., 2011 and Morais et al., 2011). Singh et al. (2016) found that, crop injuries for rice cultivars when applied with azimsulfuron. According to Souahi et al. (2016) stated that, the decrease in protein content is an indication of reduction in the growth of the plants. On other hand, rice varietal differences were significantly affected on protein content and proline amino acid (Zayed et al., 2014 and Zhou et al., 2018). The ratio of aspartate-derived concentration to glutamate-derived free amino acid determined for the japonica group was significantly lower than that for the indica group (Kamara et al., 2010).

\section{Yield attributes}

The effects of herbicides and cultivars and their interaction on rice grain yield and yield attributes are shown in Tables (4 and 4 continued). Insignificant $(\mathrm{P}<0.05)$ highly differences were observed in number of panicle per $\mathrm{m}^{2}$, number of filled grains per panicle, 1000-grains weight, grain yield per fad and harvest index were observed due to application of herbicides 
treatments under the four cultivars of rice. Contrarily to the negative impact on the physiological and biochemical parmetrs affected negatively by herbicides 
application (Tables 1-3). photosynthetic pigments were significantly reduced in the herbicide treated rice plots in the early stage of growth but the crop recovered later on. It is clear from the results that, spraying herbicides (halosulfuron-methyl, fenoxaprop-p-ethyl, bispyribac-sodium and bensulfuron-methyl inecreased significantly rice yield and yield attributes compared with control treatment. The obtained results are in accordance with those reported by Pasha et al. (2012), Thapa (2012) and Shukla et al. (2015). On other hand, the results revealed that, varietal differences were significantly $(\mathrm{p}<0.05)$ affected on rice yield and yield attributes where, Sakha $104 \mathrm{cv}$. gave the highest values for number of panicle per $\mathrm{m}^{2}, 1000$-grains weight, grain yield per fad and harvest index as compared with those recorded by EHR1, Giza 179 and Giza 178 cvs. Mean through, EHR1. gave the highest number of filled grains per panicle. Similar significant effects were reported by (Abou-Khalifa, 2012, Abou Khalifa et al., 2014, Gomaa, 2018, Khattab, 2019 and Tefera et al., 2019). Also, studied by Khwaja and Deva (2014) showed that fenoxaprop-p-ethyl, pyrasulfuron-ethyl, metasulfuron-methyl and bispyribac-sodium caused increasing tillers per hill, pancile growth, panicle weight, test weight, number of filled grain, grain yield and straw yield of rice field. Perhaps the reason for this is that there was more space to the crop competition in terms of dry matter production of weed as well as good source sink relationship which allow crop to absorb required amount of nutrient, water and sunlight for it is growth, better transfer of photosynthesis which contributes to increase the weight of of panicles and other parameters. According to the interaction effect between herbicides treatments and cultivars indicated that Sakha $104 \mathrm{cv}$. appeared to produce the highest seed index $(30.22 \mathrm{~g})$ and grain yield/fad., (5.08 ton) when were foliar application with Nominee while the lowest grain yield/ fad., (2.62 ton) was recorded by unweeded treatment with sowing Giza $179 \mathrm{cv}$.

Conclusively, from these results, it is concluded that the activity of photosynthetic pigments, total carbohydrate, protein content decreased as response to the herbicides at recommended rates and reflected on essential amino acids and non-essential amino acids under rice varieties but the crop recovered later on. Contrarily, rice yield components were significantly incresaesed due to foliar application of herbicide. On other side, Giza $178 \mathrm{cv}$. of rice was most sensitive among the selected varieties as maximum reduction in the tested biochemical content while, EHR1 gave the highest values for almost recorded physiological attributes under the current study. 
Moreover, Sakha $104 \mathrm{cv}$. appeared to produce the highest number of panicle per $\mathrm{m}^{2}$, seed index and grain yield/fad.

\section{REFERENCES}

A.O.A.C., (2000). Official Methods Of Analytical Of Association. Official Analysis Agriculture Chemists. $17^{\text {th }}$ Ed Washington. N.S.A.

Abou Khalifa, A. A., W. ELkhoby and E. M. Okasha (2014). Effect of sowing dates and seed rates on some rice cultivars. Afr. J. Agric. Res., 9(2):196-201.

Abou-Khalifa, A. A. Basyouni (2012). Evaluation of some rice varieties under different nitrogen levels. Advances in Applied Science Research, 3 (2):1144-1149.

Ahmad, M.S.A., F.J. Khan and M. Ashraf (2007). Iso-osmotic effect of $\mathrm{NaCl}$ and PEG on growth, cations and free proline accumulation in callus tissue of two indica rice (Oryza sativa L.) genotypes. Plant Growth Regul., 53: 53-63.

Ahmed, M. ., A. H. Mostafa, T. I. Milad and T.A. Mahmoud (2019). Injury Indicator of Glyphosate to Alfalfa as affected by Recurrent Selection. Alex. J. Agric. Sci. (Special Issue). 64(2): 53-62.

Amirjani, M.R. and M.Mahdiyeh (2013). Antioxidative and biochemical responses of wheat to drought stress. J. Agric. Biol. Sci., 8(4): 291-301.

Benmoussa, M., L. P. Vezina , M. Page , S. Yelle and S. Laberge (2000). Genetic polymorphism in lowmolecular-weight glutenin genes from Triticum aestivum variety Chinese Spring. Theoretical and Applied Genetics, 100(5):789-793.

Britton, G., Liaaen-Jensen S. and H. Pfander (2004). Carotenoids. Handbook Birkhauser Verlag, Basel. Switzerland.

Christias, C., Couvaraki, C., Georgopoulos, S. G., Macris, B. and Vomvoyanni, V. (1975). Protein content and amino acid composition of certain fungi evaluated for microbial protein production. Applied Microbiology, 29:250-254.

Egli, M. A., D. Low, K. R. White and J. A. Howards (1985). Effects of herbicides and herbicide analogs on ${ }^{14}$ C-leucine incorporation by suspension-cultured Solanum nigrum cells. Pesticide Biochemistry and Physiology, 24(1):112-118.

Fernández-Aparicio, M., A. Bernard, L. Falchetto, P. M. B. Chauvel, C. Steinberg, C. E. Morris, S. G.-L. A. Boari, M. Vurro, D. A. Bohan, D. C. Sands and X. Reboud (2017). Investigation of Amino Acids As 
Herbicides for Control of Orobanche minor Parasitism in Red Clover. Frontiers in Plant Science, Volume 8, Article 842, Pp:1-12.

Fideel, A. A. (1962). Location and properties of chloroplasts and pigments determination in roots. Physiol. Plants, 15: 130-147.

Gomaa, M. A., E. E. Kandil, N. R. Abdelsalam and M. A.M. Al-Jaddadi (2018). Growth, productivity of some rice cultivars in relation to nanozinc and iron fertilizer. Middle East J. Agric. Res., 7(4): 1352-1358.

Gomez, K.A. and A.A. Gomez (1991). Statistical Procedures for Agricultural Research. 2nd Ed., Jhon Wiley and Sons Inc., New York, 95-109.

Hala, K .and S. A. Ibrahim (2011). Influence of some selective herbicides on growth, yield and nutrients content of wheat (Triticum aestivum L.) plants. Journal of Basic and Applied Science Research, 1(1): 201-207.

Hanci, F. and E. Cebeci (2014). Investigation of proline, chlorophyll and carotenoids changes under drought stress in some onion (Allium cepa L.) cultivars. Turk. J. of Agricultural and Natural Sciences. Sp. Issue, 2.

Hasaneen, M. N. A., M. E. Younis and S. M. N. Tourky (2009). Plant growth, metabolism and adaptation in relation to stress conditions XXIII. Salinity-biofertility interactive effects on growth, carbohydrates and photosynthetic efficiency of lactuca sativa. Plant Omics Journal, 2(2): 60-69.

Jinendiran, Sekar, B.S. D. Kumar, H. Dahms, C. D. Arulanandam, N. Sivakumar (2019). Optimization of submerged fermentation process for improved production of $\beta$-carotene by Exiguobacterium acetylicum S01. Heliyon. 5(5).

Kamara, J. S., T. Sasanuma, S. Konishi, T. Abe (2010). Variation in free amino acid profile among some rice (Oryza sativa L.) cultivars. Breeding Science, 60(1):46-54.

Khattab, E. A. (2019). Performance Evaluation of Some Rice Varieties under the System of Planting in Egypt. Asian Journal of Research in Crop Science, 3(2): 1-10.

Khwaja, L. and S. Devas (2014). Effect of new post-emergence herbicides on yield and yield attributies and energe in transplanted rice (Oryza sativa L.). Int. J. Foresty and Crop Imporvment, 5(2):73-78.

Kumar, S. and A. K. Singh (2010). A review on herbicide 2, 4-D damage reports in wheat (Triticum aestivum L.). Journal of Chemical and Pharmaceutical Research, 2(6):118-124.

Kumar, S. (2012). Effect of herbicides on carbohydrate, protein and electrophoretic protein bands content in Triticum aestivum $\mathrm{L}$. 
International Journal of Food, Agriculture and Veterinary Sciences, 2(1):13-25.

Kushwaha, S. and P. C. Bhowmik (1999). Inhibition of pigment biosynthesis in cucumber cotyledons by isoxaflotole. Photosynthetica, 37(4): 553-558.

Morais, S., M. Correia, V. Domingues and C. D. Matos (2011). Urea Pesticides, Pesticides Strategies for Pesticides Analysis, Margarita Stoytcheva (Ed.), ISBN: 978-953-307-460-3, InTech, Available from: http:/www. intechopen.com/ articles/ show/ title / urea-pesticides.

MSTAT-C (1991). A microcomputer program for the design, management and analysis of agronomic research experiment. MSTAT Devel. Team, Michigan State Univ., USA.

Nandihalli, U. B. and P.C. Bhowmik (1992). Inhibition of chlorophyll and carotenoid biosynthesis by the herbicide ICIA-0051. Photosynthetica, 26(3): 355-362.

Omokawa, H., N. Ichizen, M. Konnai and T. Takematsu (1988). Herbicidal activity and phytotoxic properties of $\mathrm{N}$-alkyl-N'-( $\alpha, \alpha-$ dimethylbenzyl)-2,4-diamino-6-chloro-s-trizines. Agriculture Biology and Chemistry, 52(6): 1515-1519.

Pasha, H. Yousefnia, R.T. koloor and S. J. Hashemi (2012). Effects of weed control methods on yield and yield components of Iranian rice. AJAE, 3(2):59-64.

Rosenbom, A.E., J. Kjaer and P. Olsen (2010). Long-term leaching of rimsulfuron degradation products through sandy agricultural soils. Chemosphere, 79(8) 830-838.

Saari, L., Cotterman, J. and M. Primiani (2011). Machansim of sulfunyluarea herbicides resistance in broadleaf weed, Kochia scoporia. Plant Physiol., 93, 55-61.

Saha, S., S. Munda, B. C. Patra, and B. S. Satapathy (2018). Protocol for herbicides-based weed control in rice. NRRI, Indian Council of Agricultural Research, India, pp, 1-8.

Saleem, S., H. N. Tahir and U. Saleem (2011). Study of genetic variability in maize inbred lines under irrigated and drought conditions. Int. $J$. Agric. Appl. Sci., 3, 80-85.

Sands, D. C., and A. L. Pilgeram (2009). Methods for selecting hypervirulen biocontrol agents of weeds: why and how? Pest Manag. Sci., 65:581587.

Scheel, D. and J. E. Casida (1985). Sulfonylurea herbicides: growth inhibition in soybean cell suspension cultures and in bacteria correlated 
with block in biosynthesis of valine, leucine or isoleucine. Pesticide Biochemistry and Physiology, 23(3): 398-412.

Shaner, D. L. (1989). Sites of Action of Herbicides in Amino Acid Metabolism: Primary and Secondary Physiological Effects. In: Poulton J.E., Romeo J.T., Conn E.E. (eds) Plant Nitrogen Metabolism. Recent Advances in Phytochemistry, Vol 23. Springer, Boston, MA.

Shukla, U. N., V. K. Srivastava, S. Singh, U. S. Ram And A. K. Pandey (2015). Effect of seedlings age, cultivars and weed management on weed dynamics, nutrient removal and yield of rice (Oryza sativa) under system of rice intensification (SRI). Indian Journal of Agricultural Sciences,. 85 (10): 1260-1268.

Sing, T., B. D. Sharma, R. Mangat and R. S. Panwar (1996). Effect of chemical weed control on nutrient uptake by tori (Brassica compestris var. tori) and associated weeds. Annals of Biology, Ludhiana,. 12(2): 274-277.

Singh, R. (2007). Performance of Diclofop-Methyl to control weeds in wheat (Triticum aestivum) under different irrigation levels. Indian Journal of Agricultural Research, 41(1)75-78.

Singh, V., L. J. Mangi, Z. A. Ganie, B. S. Chauhan and R. K. Gupta (2016). Herbicide options for effective weed management in dry directseeded rice under scented rice-wheat rotation of western Indo Gangetic Plains. Crop Protection, 81:168-176.

Souahi, H., L. M. Amara and M. R.Djebar (2016). Effects of Sulfonylurea Herbicides on Protein Content and Antioxidants Activity in Wheat in Semi-Arid Region. International Journal of Advanced Engineering, Management and Science, 2 (9):1471-1476.

Steel, R.G.D., J.H. Torrie and D.A. Dickey (1997). Principles and Procedures of Statistics. A Biometrical Approach, $3^{\text {rd }}$ Ed. Mac Graw Hill Book Co. New Yourk, USA, 352-358.

Sundaru, M.( 1983). The growth and physiological response of several Indonesian rice varieties and paddy weeds to 2, 4-D with reference to ethylene. Memoirs of the Tokyo University of Agriculture, Tokyo, Japan. 25: 35-88.

Tagour, R. M. H. and I. S. M. Mosaad (2017). Effect of the foliar enrichment and herbicides on maize and associated weeds irrigated with drainage water. Annals of Agricultural Sciences, 62:183-192.

Tefera, W., Z. Dilnesaw, K. T/Michael, A. Adane and A. Getie (2019). Performance Evaluation of Six Rice (Oryza sativa L.) Varieties at Beles Sugar Development Project, Ethiopia. International Journal of Advanced Research in Biological Sciences, 6(2): 121-128. 
Thapa, C.B. (2012). Toxic effects of herbicides on transplanted paddy Nepalese. Journal of Biosciences. 2:5-9.

under the system of planting in Egypt. Asian Journal of Research in Crop Science, 3(2): 1-10.

Wettestein, D. (1957). Chlorophyll. Lethale under Submikroskopische Formwechsel der Plastiden. Exp. Cell Reso., 12: 427-506.

Yin, X. L., L. Jiang, N. H. Song and H. Yang (2008). Toxic reactivity of wheat (Triticum aestivum L.) plants to herbicide isoproturon. Journal of Agriculture, Food and Chemistry, 56(12): 4825-4831.

Zarzecka, K. and M. Gugala (2003). The effect of herbicide applications on the content of ascorbic acid and glycoalkaloids in potato tubers. Plant Soil Environ., 49(5): 237-240.

Zayed, B.A., A. K. Salem and O. A. M. Ali (2014). Physiological characterization of Egyptian salt tolerantrice varieties under different salinity levels. Life Sci. J., 11(10):1264-1272.

Zhou, C., Y. Huang, B. Jia, Y. Wang, Y. Wang, Q. Xu, R. Li, S. Wang, and F. Dou (2018). Effects of cultivar, nitrogen rate, and planting density on rice-grain quality. Agronomy, 8(246):1-13.

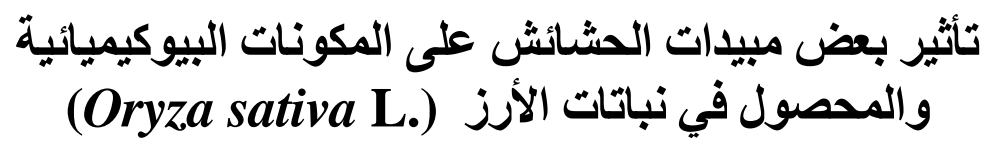

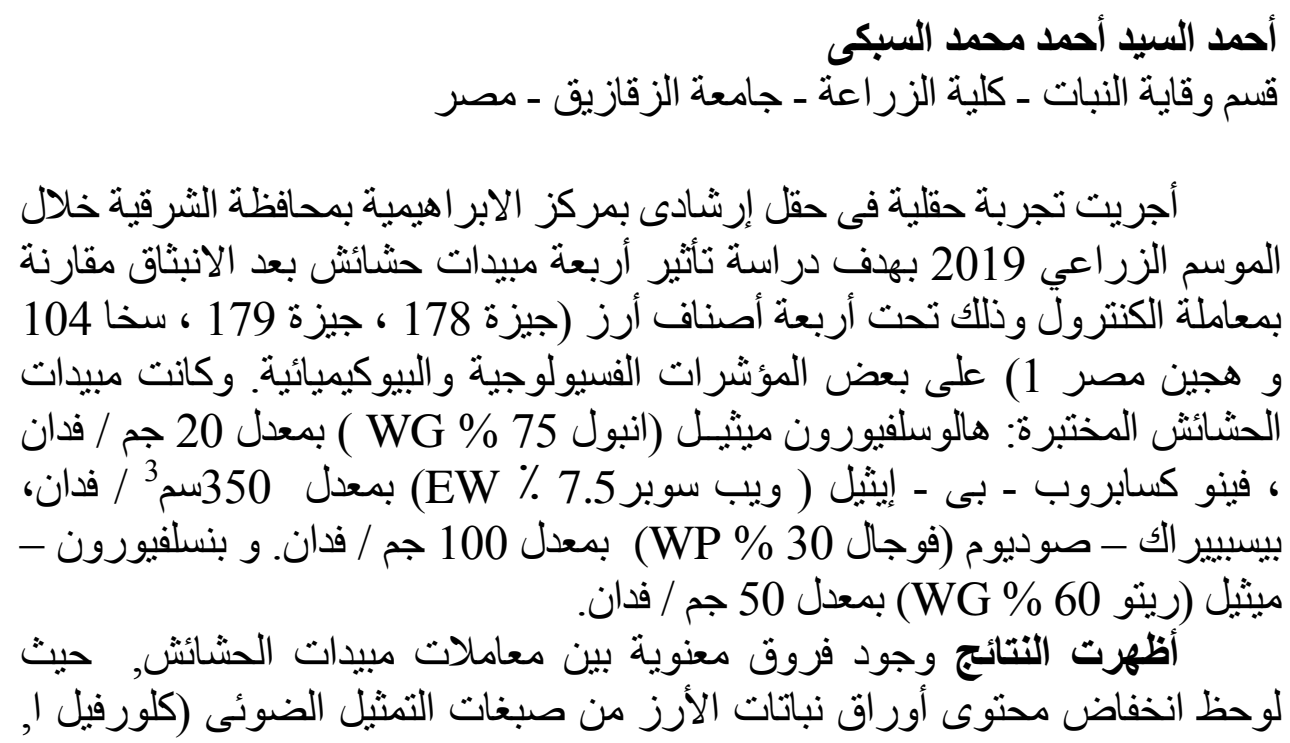


كلورفيل ب و الكاروتتيات), الكربو هيدرات الكلية , البروتين وكذلك الأحماض الأمينية

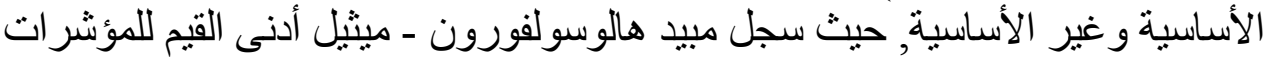

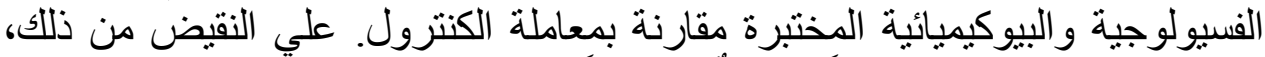

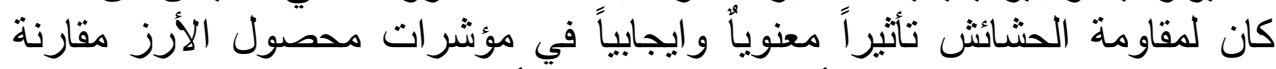

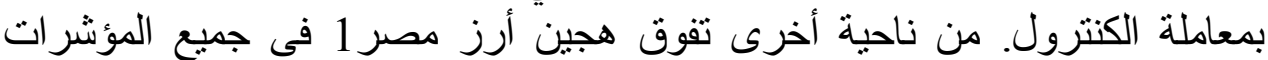

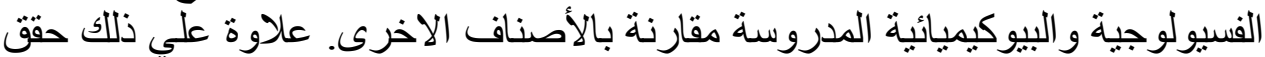

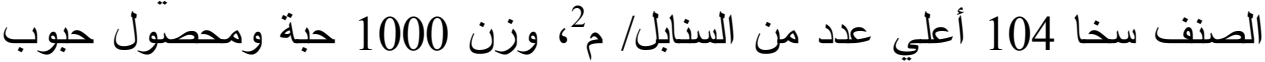

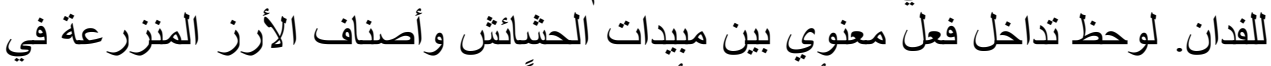

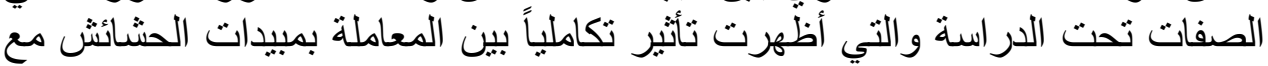

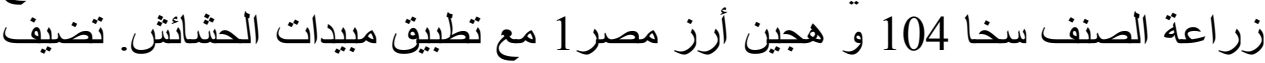

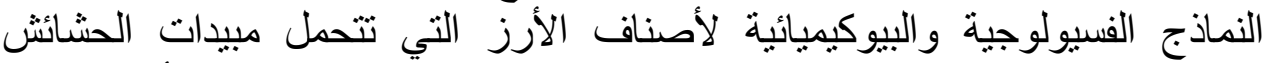
معلومات إضافية إلى معرفة درجة تحمل المحاصيل لمبيدات الحشائش من أجل الإدارة

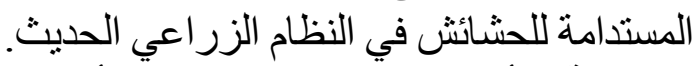

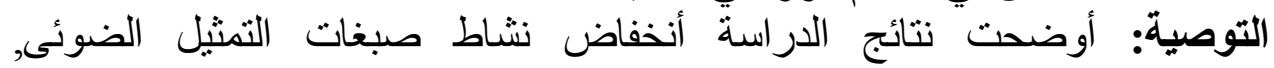

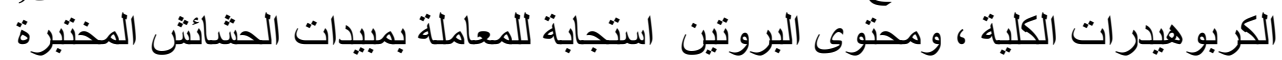

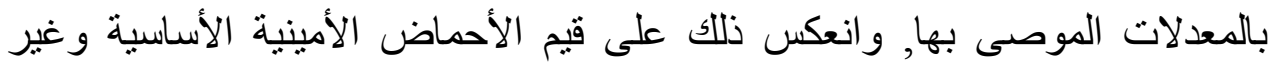
الأساسية فى أصناف الأرز المختبرة. كما أعطت مكونات محصول الأرز معنوية الأنية بدرجة كبيرة بسبب تطبيق مبيدات الحشائش. 
J. Product. \& Dev., 24(4): 885 - 903(2019) 